J. Perinat. Med.

$12(1984) 69$

\section{Amniotic fluid C-peptide and phosphatidyl glycerol in diabetic pregnancy}

O. Tydén*, C. Berne**, U. J. Eriksson***, U. Hansson****, M. Stangenberg****, B. Persson*****

* Department of Obstetrics and Gynecology, University Hospital, Uppsala, Sweden

** Department of Internal Medicine, University Hospital, Uppsala, Sweden

*** Department of Medical Cell Biology, Biomedicum, University of Uppsala, Sweden

**** Department of Obstetrics and Gynecology, Karolinska Hospital, Stockholm, Sweden

***** Department of Pediatrics, St. Göran's Hospital, Stockholm, Sweden

\section{Introduction}

In pregnancies complicated by diabetes, maternal and subsequent fetal hyperglycemia will lead to an increased fetal secretion of insulin. The degree of fetal hyperinsulinemia is reflected in the amniotic fluid concentration of C-peptide, the connecting peptide of proinsulin, which probably reaches the amniotic fluid via the fetal urine. Several investigators have shown an association between elevated levels of C-peptide in the amniotic fluid and neonatal complications in diabetic pregnancies $[15,20]$.

Neonatal disorders such as respiratory disturbances, hypoglycemia, hyperbilirubinemia and feeding difficulties may reflect delayed functional maturation of different organs. So far, only the functional maturity of the lung can be assessed prenatally, by determination of the lecithin/ sphingomyelin (L/S)-ratio, or lately by estimation of other surfactant components in the amniotic fluid [7]. Among these surface-active phospholipids, phosphatidyl glycerol is considered to be a reliable indicator of pulmonary maturity not only in normal but also in diabetic pregnancies $[2,8]$.

The aim of the present study was to assess the possibility of a relationship between the level of C-peptide and the presence of phosphatidyl glycerol in the amniotic fluid, in strictly controlled diabetic pregnancies.

\section{Curriculum vitae}

OLOF TYDÉN was born in 1947 and he received his M.D. in 1973. In 1979, he became a specialist in obstetrics and gynecology. In 1980 his doctoral thesis was accepted. Presently he is a registered physician in the Department of Obstetrics and Gynecology at the University Hospital in Uppsala, Sweden. His principal interests include fetal

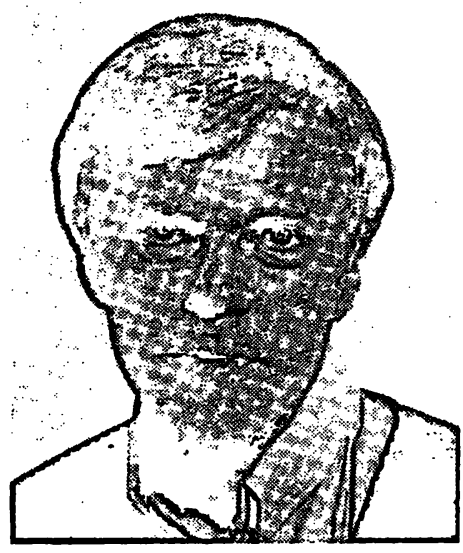
maturation and diabetic pregnancy.

\section{Materials and methods}

\section{Subjects}

The study comprised a consecutive series of 36 pregnant diabetic patients, classified as suggested by WHITE [23]. Gestational diabetes was diagnosed by a 3 hour, 50 gram oral glucose tolerance test as described earlier $[6,9]$. Twenty-one of the patients were insulin-treated gestational diabetic women (White class $\mathrm{AB}$ ) and 15 were insulindependent diabetic women (12 of classes B-D and 3 of class F). All patients were subjected to a program of strict metabolic control during their pregnancy [16]. Blood glucose levels were monitored at home by the patients either by means of reagent strips alone or by a reflecto- 
meter. The insulin dose was adjusted according to the blood glucose values with the goal being to keep the blood glucose within the physiological range, i.e. between 3.0 and $6.5 \mathrm{mmol} / 1$.

\section{Amniotic fluid investigations}

Transabdominal amniocentesis was performed at $36-37$ weeks of gestation as part of the routine program for fetal surveillance in diabetic women.

The presence or absence of phosphatidyl glycerol was assessed on centrifuged ( $1100 \times \mathrm{g} ; 5$ minutes) amniotic fluid samples, kept frozen and stored at $-20^{\circ} \mathrm{C}$ until analysis. Phosphatidyl glycerol was determined as described by HALLMAN and TERAMO [8], by two-dimensional thin-layer chromatography. The phospholipids were stained by iodine vapors and the presence of phosphatidyl glycerol was recorded as an indicator of pulmonary maturity [8]. The lower detection limit for phosphatidyl glycerol in amniotic fluid was $0.33 \mu \mathrm{g} / \mathrm{ml}$.

C-peptide in the amniotic fluid was measured by radioimmunoassay [10] after treating the samples with polyethylene glycol to remove insulinbinding: antibodies [11].

FISHER's exact probability test and the MANNWHITNEY U test were used for statistical analyses; $\mathrm{p}<0.05$ was considered as statistically significant.

\section{Results}

Amniocentesis was performed 2-3 weeks before delivery in women of White Class $A B$ and $B-D$ (Tab. I). All diabetic patients were delivered at term with the exception of 3 patients of White class F, who were delivered preterm because of pregnancy complications. The concentration of C-peptide in the amniotic fluid did not differ between White classes $A B$ and $B-D$ at the time of amniocentesis. Phosphatidyl glycerol was present in 9 of 21 patients of White class $A B$ as compared with 6 of 12 in White class B-D. It was not present in any patient of class $F$, and in this class the concentration of $\mathrm{C}$-peptide in the amniotic fluid was lower than in patients of classes B-D.

A correlation was found between the concentration of C-peptide in the amniotic fluid and the

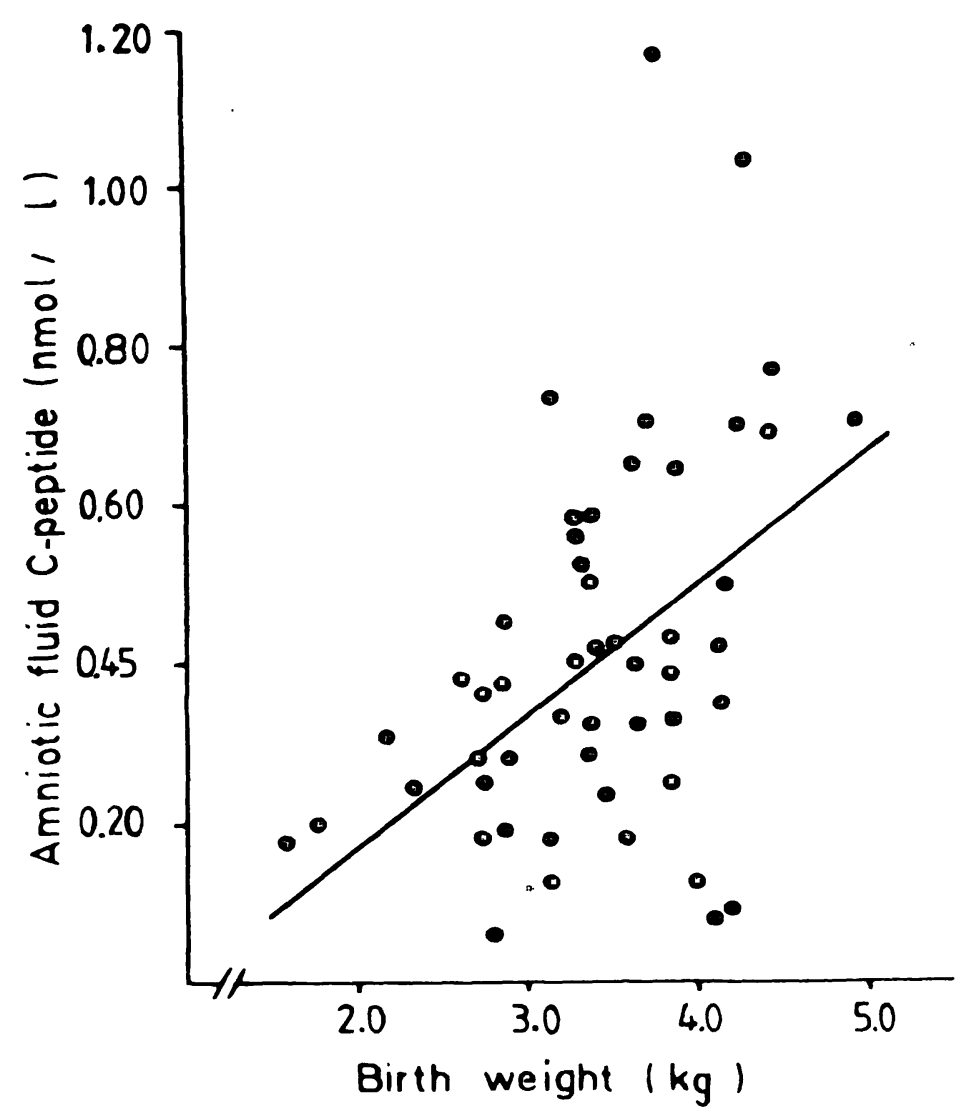

The relationship between the amniotic fluid concentration of C-peptide and the infants' birth weights.

Tab. I. Mean values \pm 2 SEM for the gestational week of amniocentesis and of delivery, birth weight, and concentration of C-peptide in the amniotic fluid, and the proportion of cases in which phosphatidyl glycerol (PG) was present in the amniotic fluid, in the different White classes.

\begin{tabular}{lllllll}
\hline & $\begin{array}{l}\text { Number of } \\
\text { patients }\end{array}$ & $\begin{array}{l}\text { Amniocentesis } \\
\text { (weeks) }\end{array}$ & $\begin{array}{l}\text { Delivery } \\
\text { (weeks) }\end{array}$ & $\begin{array}{l}\text { Birth Weight } \\
\text { (grams) }\end{array}$ & $\begin{array}{l}\text { C-peptide } \\
\text { (nmol/1) }\end{array}$ & $\begin{array}{l}\text { PG } \\
\text { Present }\end{array}$ \\
\hline White class AB & 21 & $36.4 \pm 0.8$ & $39.3 \pm 0.7$ & $3557 \pm 145$ & $0.43 \pm 0.04$ & $9 / 21$ \\
White class B-D & 12 & $36.5 \pm 1.2$ & $38.6 \pm 1.0$ & $3448 \pm 188$ & $0.51 \pm 0.08$ & $6 / 12$ \\
White class F & 3 & $35.3 \pm 2.3$ & $36.0 \pm 2.8$ & $2595 \pm 1160$ & $0.32 \pm 0.1$ & $0 / 3$ \\
\hline
\end{tabular}


scrbequent birth weight of the infants $(r=0.50$; $\mathrm{s}<0.01$ ) (Fig. 1). The C-peptice concentrations diec not differ. on the aversge, between patients in whom phoshatidyl glycerol was present in the amaiotic fluid $(n=15 ; 0.56 \pm 0.06 \mathrm{nmol} / \mathrm{l})$ and those in whom it was absent $(n=21$ : $0.43 \doteq 0.05 \mathrm{nmol} / \mathrm{l})$. The gestational age at amniocentesis did not differ between these two groups. Two cases of minor respiratory disorders (transient tachypnea, pneumothorax) occurred in infants of the group in which phosphatidyl glycerol was present. These infants were delivered by Cesarean section from women with gestational diabetes at term after an uncomplicated prenatal course.

No attempt was made to correlate phosphatidyl glycerol to the neonatal outcome, because of the time lag of more than 2 weeks between amniocentesis and delivery in White classes $A B$ and B-D.

\section{Discussion}

The main observation in this study was that the biochemical maturation of the fetal lung was not disturbed to any appreciable degree by maternal diabetes. Phosphatidyl glycerol was present in 40 per cent of the diabetic pregnancies which is a figure that corresponds to our findings in nondiabetic pregnancies at a comparable gestational age (36 weeks) [22] and is also similar to reports of other investigators $[1,3]$.

This apparently normal degree of fetal lung maturation is probably attributable to the strict control of the diabetic state during the pregnancies. Indeed, in these women the achieved metabolic control of maternal blood glucose levels approached normal values, however, there was evidence of some degree of fetal hyperinsulinemia, as assessed by the concentration of C-peptide in the amniotic fluid. Although the mean value for this concentration was close to that found previously for diabetic pregnancies with an uneventful neonatal outcome $(0.51 \pm 0.9 \mathrm{nmol} / \mathrm{l})$, it was

\section{Summary}

The concentrations of C-peptide and phosphatidyl glycerol in the amniotic fluid were determined in 36 pregnant significantly higher than that for non-diabetic pregnancies $(0.18 \pm 0.02 \mathrm{nmol} / \mathrm{l})$ [17] .

The C-peptide level in anniotic fluid in the present study did not discriminate between the presence or absence of phosphatidyl glycerol. This observation is in accordance with previous findings in diabetic pregnancies in that there was no correlation between the C-peptide level and the L/S ratio in the amniotic fluid [21]. nor between the C-peptide level in cord blood and the occurrence of RDS in the newborn infant [19].

The hypothesis that hyperinsulinemia per se' is the major factor underlying the disturbed surfactant production in diabetic pregnancy can be challenged. According to this hypothesis. one mechanism by which insulin exerts its inhibitory influence on lung maturation could be by decreasing the availability of substrates for surfactant synthesis. Thus, the breakdown of lung glycogen. which is the major carbohydrate source for surfactant synthesis, could be inhibited by excess insulin. The marked changes in the concentration of insulin receptors that occur during development of the fetal rat lung [18] suggest the importance of another variable that could significantly modulate glycogen metabolism in the lung. It can be speculated that a delayed disappearance of insulin receptors and an increased receptor affinity for insulin in the fetal lung in the offspring of diabetic women could lead to enhanced insulin sensitivity and hence, a decrease in glycogenolysis and in surfactant production. Interestingly, monocytes from infants of mothers with gestational diabetes have more insulin receptors than normal, and these receptors also show an increased affinity for insulin [14]. Another possibility that is supported by experimental data $[4,5]$ is that hyperglycemia per se could lead to impaired glycogen degradation and decreased surfactant production.

In conclusion the present study shows that with rigorous metabolic control of the pregnant diabetic patient, the presence or absence of phosphatidyl glycerol shows no apparent relationship to the level of C-peptide in amniotic fluid.

diabetic women. Twenty-one patients who werc being treated with insulin for gestational diabetes as well 
as 15 patients who were insulin dependent were studied. All patients were subjected to a program of strict metabolic control, and amniocentesis was performed at gestational week 36-37. Phosphatidyl glycerol was present in the amniotic fluid in 15 cases and absent in 21 . The mean concentration of C-peptide did not differ whether phosphatidyl glycerol was present or absent. (C-peptide: $0.56 \pm 0.06$ and $0.43 \pm 0.05 \mathrm{nmol} / 1$ respectively). Although the mean value for amniotic fluid C-peptide in both groups was close to that in diabetic pregnancies with an uneventful neonatal outcome, it was significantly higher than that in non-diabetic pregnancies, indicating minor fetal hyperinsulinemia. The level of C-peptide in the amniotic fluid showed a correlation to the subsequent birthweight of the infant $(r=0.50 ; p<0.01)$. It is concluded that with rigorous metabolic control of the pregnant diabetic patient, the presence or absence of phosphatidyl glycerol, as an index of fetal lung maturity, is apparently not related to the level of C-peptide in the amniotic fluid.

Key words: Amniotic fluid, C-peptide, diabetes in pregnancy, phosphatidyl glycerols, prenatal diagnosis.

\section{Zusammenfassung}

C-Peptid und Phosphatidylglycerol im Fruchtwasser diabetischer Schwangerer.

Wir bestimmten die Konzentrationen von C-Peptid und Phosphatidylglycerol im Fruchtwasser bei 36 schwangeren Diabetikerinnen. Bei 21 Frauen bestand ein Schwangerschaftsdiabetes, der mit Insulin eingestellt wurde; 15 Frauen hatten schon vor der Schwangerschaft einen insulinabhängigen Diabetes. Alle Patientinnen unterlagen einer strengen Stoffwechselkontrolle. Die Amniozentese wurde zwischen der 36. und 37. Schwangerschaftswoche durchgeführt. In 15 Fruchtwasserproben konnte Phosphatidylglycerol nachgewiesen werden, bei den übrigen 21 Proben nicht. Die mittlere C-Peptid-Konzentration war unabhängig von der Anwesenheit von Phosphatidylglycerolkonzentration $(0,56 \pm 0,06 \mathrm{nmol} / \mathrm{l}$ bei Phosphatidyl- glycerolnachweis, $0,43 \pm 0,05 \mathrm{nmol} / 1$, wenn kein Phosphatidylglycerol nachweisbar war). Wenn auch die mittlere C-Peptidkonzentration im Fruchtwasser in beiden Gruppen vergleichbar war mit Werten bei diabetischen Schwangeren, deren Neugeborene keine neonatalen Komplikationen zeigten, so war sie doch signifikant höher als die Konzentration bei nicht-diabetischen Schwangeren, was wir als Hinweise für einen fetalen Hyperinsulinismus werteten. Der Gehalt an C-Peptid im Fruchtwasser korrelierte mit dem tatsächlichen Geburtsgewicht des Kindes $(r=0,50 ; p<0,01)$. Wir glauben, daß bei strenger Stoffwechselkontrolle einer diabetischen Schwangeren der Nachweis von Phosphatidylglycerol als Index der fetalen Lungenreife keinen Zusammenhang mit dem C-PeptidSpiegel im Fruchtwasser aufweist.

Schlïsselwörter: C-Peptid, Diabetes und Schwangerschaft, Fruchtwasser, Phosphatidylglycerol, pränatale Diagnose.

\section{Résumé}

Peptide-C et phosphatidyl glycerol dans le liquide amniotique au cours de la grossesse des diabetiques

On a déterminé les concentrations de peptide-C et de phosphatidyl glycerol dans le liquide amniotique de 36 femmes enceintes diabétiques. 21 femmes étaient en cours de traitement par insuline pour un diabète gestationnel et 15 étaient insulinodépendantes. Toutes ces patientes étaient soumises à un programme de strict contrôle métabolique et une amniocentèse a été réalisée au cours de la 36-37ème semaine gestationnelle. Il y avait du phosphatidyl glycerol dans le liquide amniotique dans 15 cas et pas dans 21 . La concentration moyenne de peptide-C n'était pas différente qu'il $y$ ait ou non $\mathrm{du}$ phosphatidyl glycerol (respectivement, peptide-C $=0,56 \pm 0,06$ et $0,43 \pm 0,05 \mathrm{nmol} / \mathrm{l})$. Bien que la valeur moyenne de peptide-C dans le liquide amniotique ne fît appel dans les 2 groupes qu'aux grossesses diabétiques avec un devenir néonatal sans problème, cette valeur n'était significativement plus élevée que dans les grossesses chez les non-diabétiques, ce qui indique une hyperinsulinémie fœtale minime. Le taux de peptide-C dans le liquide amniotique a montré une corrélation avec le poids de naissance ultérieur de l'enfant $(r=0,50 ; p<0,01)$. Les auteurs concluent qu'avec un contrôle métabolique rigoureux chez les diabétiques enceintes, la présence ou l'absence de phosphatidyl glycerol, en tant qu'index de la maturité pulmonaire fœtale, n'est apparemment pas en corrélation avec le taux de peptide-C du liquide amniotique.

Mots-clés: Diabète gravidique, diagnostic prénatal, liquide amniotique, phosphatidyl glycerol, peptide-C.

Acknowledgement: This study was supported by grants from the Swedish Diabetes Association, the Expressen Prenatal Research Fund, Tielman's Fund for Pediatric Research, the Swedish Society for Medical Research and the Swedish Medical Research Council (project 19X-03787). 


\section{Bibliography}

[1] BENT, A. E., J. H. GRAY, E. R. LUTHER, M. OULTON, L. J. PEDDLE: Assessment of fetal lung maturity: Relationship of gestational age and pregnancy complications to phosphatidyl glycerol levels. Am. J. Obstet. Gynaecol. 142 (1982) 664-669

[2] CUNNINGHAM, M.D., N.S.DESAI, S.A.THOMPSON: Amniotic fluid phosphatidylglycerol in diabetic pregnancies. Am. J. Obstet. Gynecol.131 (1978) 719-724

[3] CUNNINGHAM, M.D., H.MCKEAN, D.GILLESPIE, I. GREENE: Improved prediction of fetal lung maturity in diabetic pregnancy: A comparison of chromatographic methods. Am. J. Obstet. Gynecol. 142 (1982) 197-208

[4] ERIKSSON, U., O. TYDÉN, C. BERNE: Glycogen content and lipid biosynthesis in the lungs of fetuses of diabetic rats. Biol. Research in Pregnancy 4 (1983) 103-106

[5] GEWOLB, I., C. BARRETT, C. WILSON, I. WARSHAW: Delay in pulmonary glycogen degradation in fetuses of streptozotocin diabetic rats. Pediatr. Res. 16 (1982) 869-873

[6] GILLMER, M.D.G., R.W. BEARD, F.M.BROOKE, N. W. OAKLEY: Carbohydrate metabolism in pregnancy. Part II. Relation between maternal glucose metabolism in the newborn. Br. Med. J. 3 (1975) 402-404

[7] HALlmAN, M., M. V. KULOVICH, E. KIRKPATRICK, R. SUGARMAN, L. GLUCK: Phosphatidyl inositol (PI) and phosphatidyl glycerol (PG) in amniotic fluid: Indices of lung maturity. Am. J. Obstet. Gynecol. 125 (1976) 613-617

[8] HALlMAN, M., K. TERAMO: Amniotic fluid phospholipid profile as a predictor of fetal maturity in diabetic pregnancies. Obstet. Gynecol. 54 (1979) 703-707

[9] HARDING, P.E., N.W. OAKLEY, V.WYNN: Reproducibility of oral glucose tolerance data in normal and mildly diabetic subjects. Clin. Endocrinol. 2 (1973) 387-395

[10] HEDING, L. G. Radioimmunological determination of human C-peptide in serum. Diabetologia 11 (1975) $541-548$

[11] HEDING, L.G., T.KASPERSKA-CZYZYKOWA: Cpeptide and proinsulin after oral glucose. Acta. Med. Scand. suppl. 639 (1980) 33-36

[12] KULOVICH, M. V., L. GLUCK: The lung profile II. Complicated pregnancy. Am.J. Obstet. Gynecol. 135 (1979) 64-70

[13] LIN, C. C., P. RIVER, A. H. MOAWAD, R. I. LOWENSOHN, P. M. BLIX, M. ABRAHAM, A. H. RUBENSTEIN: Prenatal assessment of fetal outcome by amniotic fluid C-peptide levels in pregnant diabetic women. Am. J. Obstet. Gynecol.141 (1981) 671-676
[14] NEUfELD, N. D., S. A. KAPLAN, B. M. LIPPE, M. SCOTT: Increased monocyte receptor binding of (125I) insulin in infants of gestational diabetic mothers. J. Clin. Endocrinol Metab. 47 (1978) $590-$ 595

[15] OGATA, E. S., N. FREINKEL, B. E. METZGER, R. L. PHE LPS, R. DEPP, J. J. BOEHM, S. L. DOOLEY: Perinatal islet function in gestational diabetes: Assessment by cord plasma C-peptide and amniotic fluid insulin. Diabetes Care 3 (1980) 425-429

[16] PERSSON, B., J. GENTZ, N. O. LUNELL: Diabetes in pregnancy. In: Reviews in Perinatal Medicine, Vol. 2. E. M. SCARPELLI and E. V. COSMI eds. New York Raven Press (1978) 1-55

[17] PERSSON, B., L. G. HEDING, N. O. LUNELL, H. PSCHERA, M. STANGENBERG, J. WAGER: Fetal betacell function in dabetic pregnancy. Amniotic fluid concentrations of proinsulin, insulin, and C-peptide during the last trimester of pregnancy. Am. J. Obstet. Gynecol. 144 (1982) 455-459

[18] SODOYEZ-GOFFAUX, F.R., J.C. SODOYEZ, C. J DE VOS: Insulin receptors in the fetal rat lung. A transient characteristic of fetal cells? Pediatr. Res. 15 (1981) 1303-1307

[19] SOSENKO, I. R., J. L. KITZMILlER, S. W. LOO, P.BLIX, A.H.RUBENSTEIN, K.H.GABBAY: The infant of the diabetic mother. Correlation of increased cord C-peptide levels with macrosomia and hypoglycemia. N. Engl. J. Med. 301 (1979) 859-862

[20] STANGENBERG, M., B. PERSSON, V. VACLAVINKOVA: Amniotic fluid volumes and concentrations of C-peptide in diabetic pregnancies. Br. J. Obstet. Gynaecol. 89 (1982) 536-542

[21] TCHOBROUTSKY, G., I. HEARD, C. TCHOBROUTSKY, E. ESCHWEGE: Amniotic fluid C-peptide in normal and insulin-dependent diabetic pregnancies. Diabetologia 18 (1980) 289-292

[22] TYDÉN, O., C. BERNE, U.ERIKSSON, H. ÅGREN: Estimation of fetal maturity by amniotic fluid cytology, creatinine, lecithin/sphinogomyelin ratio and phosphatidyl glycerol. Obstet. Gynecol. Invest. 16 (1983) 317-326

[23] WHITE, P.: Pregnancy and diabetes. Medical aspects. Med. Clin. North. Am. 49 (1965) 1015-1024

Received October 17, 1983. Accepted January 9, 1984.

Olof Tydén, M. D.

Dept. of Obstet. \& Gynecology

University Hospital

S-75185 Uppsala/Sweden 
' 